\section{'NuMex Solano' Onion}

\author{
Christopher S. Cramer' ${ }^{1}$ and Joe N. Corgan ${ }^{2}$ \\ Department of Agronomy and Horticulture, Box 30003, MSC 3Q, New Mexico \\ State University, Las Cruces, NM 88003-0003
}

Additional index words. Allium cepa, Fusarium basal rot, Fusarium oxysporum f. sp. cepae, Phoma terrestris, pink root

The New Mexico State Univ. Agricultural Experiment Station announces the release of 'NuMex Solano' onion (Allium cepa L.), an open-pollinated, late-maturing, single-centered, high-yielding, pink-root and bolting resistant, firm to hard, white, round globe onion for fall seeding in southern New Mexico and similar environments, maturing in late June when fall seeded in Las Cruces, N.M.

\section{Origin}

'NuMex Solano' originated from four individual paired crosses between a bolting resistant selection of 'Ben Shemen' and 'Southport White Globe'. 'Ben Shemen' is an intermediate-day, open-pollinated, pink root susceptible, hard, yellow onion variety that originated in Israel (Corgan, 1996b) and believed to be derived from a selection known as 'Riverside Sweet Spanish'. 'Ben Shemen' is thought to be entirely normal (N) cytoplasm. 'Southport White Globe' originated from the onion growing district in Southport, Conn. (Magruder et al., 1941). It is an intermediate-day, white onion commonly grown in the northern United States for its firm to hard, medium-sized, slightly flattened to slightly ovalshaped bulbs that are relatively high in soluble solids and pungency, and can be stored for long periods of time. 'Southport White Globe' is not grown in southern New Mexico.

The initial crosses were made in 1979 by making four individual paired crosses between the two parents in separate pollination cages using blue bottle flies as the pollination vector. Seed was collected from the 'Ben Shemen' parents and planted. The following year, white colored bulbs with good pink root resistance, bolting resistance, round bulb shape, hard bulb firmness, and clear white bulb scale color were selected in 1980. Selection was done at field maturity from fall seeding near Las Cruces, N.M. The selections were made from fields that contained high inoculum levels for Phoma terrestris, causal organism for pink root, and Fusarium oxysporumf. sp. cepae, causal organism for Fusarium basal rot (FBR). The selected bulbs were intercrossed and the resulting seed was planted in 1981. In 1982, all yellow bulbs were selected from the population and were

Received for publication 15 Apr. 2002. Accepted for publication 19 Aug. 2002. This research was funded by the NMSU Agricultural Experiment Station and the New Mexico Dry Onion Commission.

${ }^{1}$ Assistant Professor of Horticulture.

${ }^{2}$ Professor Emeritus and Jose Fernandez Chair of Crop Production. intercrossed in 1983. Yellow bulbs were selected because they would possess two recessive alleles at the $I$ (color inhibitor) locus. Any white bulbs that resulted from crosses between yellow bulbs would have to be homozygous recessive at both the $I$ and $C$ loci (iicc) (Cramer and Havey, 1999). The resulting seed was collected and planted. In 1984, a group of white bulbs that were highly variable for bulb shape, bulb maturity, and pink root resistance, were selected and intercrossed the following year. The progeny were all white. The genetics for this white bulb color is iicc (recessive white). In 1986, 1988, 1990, 1992, 1994, 1996, and 1998 , selections were made using phenotypic recurrent selection, and each year's selections were intercrossed to form the next generation. For each selection, bulbs that possessed earlier maturity than 'Southport White Globe, uniform maturity, pink root and bolting resistance; round, uniform shape; hard bulb firmness; and clear white scale color were selected. For the last three selections, bulbs were selected that possessed a single growing point when cut transversely at the vertical center of the bulb. After the 1998 selection, 98 bulbs were planted in an isolation cage and seed was harvested from each bulb.

Selection for bolting resistance was done from field plantings that possessed $70 \%$ or more plants with seedstalks. Seed was planted around 1 Sept. to induce seedstalk production. This date is 3 to 4 weeks earlier than the earliest recommended planting date for fall-planted onions in southern New Mexico. Selection for pink root resistance was accomplished by planting selections in fields that were severely infested with $P$. terrestris, the causal organism of pink root. At bulb maturity, bulbs were rated for the incidence of pink root on their root system. Only bulbs that possessed a healthy root system with minimal symptoms of pink root were selected.

Selection for bulb shape was for a round, globe shape. Selection for bulb shape uniformity was for bulbs of the same size to possess the same desired shape. Selection for bulb scale color was based on the color of the dry outer bulb scales. Selection for bulb or scale color was for a color that was clear white without any greening or brown discoloration. Selection for bulb shape and color was subjective, based on visual observation. Selection for bulb firmness was based on a subjective evaluation of the amount of bulb scale resistance when a force was applied to the bulb. Selection for bulb maturity was to select bulbs that matured the third to fourth week of June. Selection for a single growing point per bulb was accomplished by transversely cutting selected bulbs at the vertical center of each bulb. Bulbs with a single growing point or multiple growing points within $1.3 \mathrm{~cm}$ from the center of the bulb were selected and advanced to the next cycle by planting the bottom half of the bulb.

In 2000, selections were made using half-sib family recurrent selection. A total of 98 half-sib families were evaluated in four replications. The number of plants out of 40 plants per plot that formed premature seedstalks was counted to get a measure of bolting resistance. The root systems of 30 randomly selected bulbs per plot were rated for pink root severity using a subjective rating of 1 (no pink roots) to 9 (heavily infected roots). The basal plate of 30 randomly selected bulbs was cut transversely, and the severity of FBR was rated, using a subjective rating of 1 (no diseased tissue) to 9 (70\% or more diseased tissue). The percentage of diseased bulbs (either pink root or FBR) was calculated using the rated bulbs. For the purpose of selection, an average pink root [Average $\mathrm{PR}=[(10$-rating $)+(100$-incidence $) / 10] / 2]$ and Fusarium basal rot $[$ Average FBR $=[(10$-rating $)$ $+(100$-incidence $) / 10] / 2$ ] value was assigned to each plot based on the average of the severity rating and incidence percentage for each disease. Bulbs that possessed the best quality traits (round bulb shape, hard bulb firmness, clean white dry scale color, multiple dry scale layers) were selected for each plot. Thirty bulbs per plot were cut transversely at their vertical centers. The percentage of bulbs with single growing points was determined by counting the number of bulbs with a single growing point (single center) or multiple growing points located within $1.3 \mathrm{~cm}$ of the bulb's center if the bulb was larger than $10 \mathrm{~cm}$ in diameter. A weighted index (WI) was formed for each plot that equally weighted each measured trait: $\mathrm{WI}=0.2[(100$-bolting percentage $) / 10]$ +0.2 (10-Average pink root) $+0.2(10$-Average FBR $)+0.2($ Percentage single centers/10) + 0.2(Number of bulbs selected/2.4). Ten half-sib families that had the highest weighted index were selected and the bulbs from their respective plots were massed and intercrossed the following year to create 'NuMex Solano'.

\section{Description and performance}

'NuMex Solano' is an intermediate-day, round onion that matures from 13 to 21 June when fall seeded in Las Cruces, N.M.

Suggested planting dates at Las Cruces are 20 Sept. to 1 Oct. 'NuMex Solano' has excellent yield, firmness, pink root resistance, bolting resistance, high percentage of single-centered bulbs, round shape, good scale quality, and midto-late June maturity. 'NuMex Solano' matures later than any other fall seeded white onion cultivar tested in southern New Mexico.

Replicated field trials were conducted in 1997-98(NMSU 97-12), 1998-99(NMSU9712), 1999-2000 (NMSU99-99), and 2000-2001 (NMSU 99-99) comparing 'NuMex Solano' to 'NuMex Crispy' (Corgan, 1996a) (Tables 1-3). In each test year, 'NuMex Solano' matured later (9 to 22 days) than 'NuMex Crispy' (Tables 1 
Table 1. Performance of 'NuMex Solano' as compared to 'NuMex Crispy' when grown on soil moderately infested with the pink root pathogen (Phoma terrestris) and the Fusarium basal rot pathogen (Fusarium oxysporum f. sp. cepae) during the 1997-98 and 1998-99 growing seasons in southern New Mexico.

\begin{tabular}{|c|c|c|c|c|c|c|c|c|}
\hline Cultivar & $\begin{array}{c}\text { Maturity } \\
\text { date }^{z}\end{array}$ & $\begin{array}{c}\text { Plants } \\
\text { /plot }\end{array}$ & $\begin{array}{c}\text { Seedstalks } \\
(\%)^{y}\end{array}$ & $\begin{array}{c}\text { Pink root } \\
\text { severity rating }\end{array}$ & $\begin{array}{l}\text { Marketable } \\
\text { yield }(\%)^{\mathrm{w}}\end{array}$ & $\begin{array}{c}\text { Marketable yield } \\
\left(\mathrm{t} \cdot \mathrm{ha}^{-1}\right)^{\mathrm{v}}\end{array}$ & $\begin{array}{l}\text { Avg bulb } \\
\text { wt (g) }\end{array}$ & $\begin{array}{c}\text { Single } \\
\text { centers }(\%)^{t}\end{array}$ \\
\hline \multicolumn{9}{|c|}{ 1997-98 (16 Sept. 1997 planting date) } \\
\hline NuMex Solano & 20 June & 54 & 10.1 & 2.2 & 93 & 53.2 & 275 & ------ \\
\hline \multirow[t]{2}{*}{ NuMex Crispy } & 3 June & 72 & 23.6 & 1.3 & 88 & 57.6 & 292 & ------ \\
\hline & $* * *$ & $* *$ & $*$ & NS & NS & NS & NS & ------ \\
\hline \multicolumn{9}{|c|}{ 1998-99 (15 Sept. 1998 planting date) } \\
\hline NuMex Solano & 13 June & 35 & 11.2 & 4.0 & 85 & 46.3 & 409 & 64.7 \\
\hline \multirow[t]{2}{*}{ NuMex Crispy } & 4 June & 51 & 2.8 & 2.4 & 84 & 69.6 & 392 & 49.9 \\
\hline & $*$ & $* *$ & NS & * & NS & NS & NS & $*$ \\
\hline
\end{tabular}

${ }^{\mathrm{z}} \mathrm{An}$ entry was harvested when all four replications had $80 \%$ of their tops down within the plot. A plot was considered matured when $80 \%$ of the tops were down.

${ }^{y}$ The percentage of seedstalks was determined at harvest and calculated by dividing the number of plants with seedstalks by the total number of plants per plot.

${ }^{x}$ Root systems of 25 bulbs per plot were rated based on a scale of 1 (no infected roots) to 9 (completely infected roots).

wercentage of marketable yield was calculated by dividing marketable bulb weight by total bulb weight.

"Marketable bulb yield was calculated by weighing the marketable bulbs per plot and adjusting the plot size to one acre.

"Average bulb weight was calculated by dividing the marketable bulb weight by the number of marketable bulbs.

'The percentage of bulbs with single centers (single growing point) was determined by cutting each bulb transversely at the vertical center and measuring the number of growing points that extended $1.3 \mathrm{~cm}$ beyond the bulb's center.

Ns, *,**,**** Nonsignificant, significant at $P=0.05,0.01$, and 0.001 , respectively.

Table 2. Performance of 'NuMex Solano' as compared to 'NuMex Crispy' when grown on soil moderately infested with the pink root pathogen (Phoma terrestris) and the Fusarium basal rot pathogen (Fusarium oxysporum f. sp. cepae) during the 1999-2000, and 2000-2001 growing seasons in southern New Mexico.

\begin{tabular}{|c|c|c|c|c|c|c|c|}
\hline Cultivar & $\begin{array}{l}\text { Maturity } \\
\text { date }^{\mathrm{z}}\end{array}$ & $\begin{array}{l}\text { Plants } \\
\text { /plot }\end{array}$ & $\begin{array}{c}\text { Seedstalks } \\
(\%)^{\mathrm{y}}\end{array}$ & $\begin{array}{c}\text { Pink root } \\
\text { severity rating }\end{array}$ & $\begin{array}{c}\text { Pink root } \\
\text { incidence }(\%)^{\mathrm{w}}\end{array}$ & $\begin{array}{l}\text { Fusarium basal rot } \\
\text { severity rating }^{\mathrm{v}}\end{array}$ & $\begin{array}{l}\text { Fusarium basal } \\
\text { rot incidence (\%) }\end{array}$ \\
\hline \multicolumn{8}{|c|}{ 1999-2000 (20 Sept. 1999 planting date) } \\
\hline NuMex Solano & 21 June & 49 & 2.1 & 2.1 & 87.0 & 2.3 & 44.0 \\
\hline \multirow[t]{2}{*}{ NuMex Crispy } & 31 May & 48 & 0.5 & 1.5 & 59.0 & 2.4 & 48.0 \\
\hline & $* * *$ & NS & NS & $* *$ & NS & NS & NS \\
\hline \multicolumn{8}{|c|}{ 2000-2001(14 Sept. 2000 planting date) } \\
\hline NuMex Solano & 16 June & 46 & 1.1 & 1.8 & 63.0 & 1.7 & 26.0 \\
\hline \multirow[t]{2}{*}{ NuMex Crispy } & 29 May & 53 & 6.1 & 1.8 & 56.0 & 2.4 & 62.0 \\
\hline & $* * *$ & NS & $*$ & NS & NS & NS & NS \\
\hline
\end{tabular}

${ }^{2}$ An entry was harvested when all four replications had $80 \%$ of their tops down within the plot. A plot was considered matured when $80 \%$ of the tops were down.

${ }^{y}$ The percentage of seedstalks was determined at harvest and calculated by dividing the number of plants with seedstalks by the total number of plants per plot.

${ }^{x}$ Root systems of 25 bulbs per plot were rated based on a scale of 1 (no infected roots) to 9 (completely infected roots).

"Percentage of bulbs with pink root.

${ }^{v}$ Cut basal plates of 25 bulbs per plot were rated based on a scale of 1 (no disease tissue) to 9 (70\% or more of basal plate decayed).

"Percentage of bulbs with Fusarium basal plate rot.

Ns, ${ }^{*}, * * * * * *$ Nonsignificant or significant at $P=0.05,0.01$, and 0.001 , respectively.

Table 3. Performance of 'NuMex Solano' as compared to 'NuMex Crispy' when grown on soil moderately infested with the pink root pathogen (Phoma terrestris) and the Fusarium basal rot pathogen (Fusarium oxysporum f. sp. cepae) during the 1999-2000, and 2000-001 growing seasons in southern New Mexico.

\begin{tabular}{lcccc}
\hline Cultivar & $\begin{array}{c}\text { Marketable } \\
\text { yield }(\%)^{\mathrm{z}}\end{array}$ & $\begin{array}{c}\text { Marketable yield } \\
\left(\mathrm{t} \cdot \mathrm{ha}^{-1}\right)^{\mathrm{y}}\end{array}$ & $\begin{array}{c}\text { Avg bulb } \\
\text { wt }(\mathrm{g})^{\mathrm{x}}\end{array}$ & $\begin{array}{c}\text { Single } \\
\text { centers }(\%)^{\mathrm{w}}\end{array}$ \\
\hline & & $1999-2000$ & & \\
NuMex Solano & 75 & 47.1 & 306 & 74.0 \\
NuMex Crispy & 86 & 73.1 & 414 & 58.7 \\
& NS & $*$ & NS & $*$ \\
NuMex Solano & 94 & $2000-2001$ & 426 & 68.7 \\
NuMex Crispy & 93 & 75.0 & 423 & 27.0 \\
& NS & 79.7 & NS & $*$ \\
\hline
\end{tabular}

${ }^{2}$ Percentage of marketable yield was calculated by dividing marketable bulb weight by total bulb weight. ${ }^{y}$ Marketable bulb yield was calculated by weighing the marketable bulbs per plot and adjusting the plot size to 1 ha.

${ }^{x}$ Average bulb weight was calculated by dividing the marketable bulb weight by the number of marketable bulbs.

${ }^{\mathrm{w}}$ The percentage of bulbs with single centers (single growing point) was determined by cutting each bulb transversely at the vertical center and measuring the number of growing points that extended $1.3 \mathrm{~cm}$ beyond the bulb's center.

Ns, "Nonsignificant or significant at $P=0.05$, respectively. 
and 2). For three years, 'NuMex Solano' possessed a higher percentage of bulbs with single centers than 'NuMex Crispy' (Tables 1 and 3). For the first two test years, 'NuMex Solano' produced fewer plants per plot than 'NuMex Crispy'; however, bulb yield and size were comparable between the two cultivars (Table 1). In 1997-98 and 2000-01, 'NuMex Solano' produced fewer seedstalks (less bolting) than 'NuMex Crispy' (Tables 1 and 2). For 2 years, 'NuMex Solano' had a higher pink root severity rating than 'NuMex Crispy' (Tables 1 and 2 ). The higher pink root severity for 'NuMex Solano' was likely due to later maturity in warmer weather, resulting in a higher level of disease pressure. Pink root incidence and Fusarium basal rot severity and incidence of 'NuMex Solano' were comparable to that of
'NuMex Crispy' (Table 2). In 1999-2000, 'NuMex Solano' produced a lower bulb yield than 'NuMex Crispy' while bulb yield of the two cultivars was comparable in the other three years (Tables 1 and 3 ). The percentage of marketable bulb yield and average bulb weight of 'NuMex Solano' was comparable to that of 'NuMex Crispy' (Tables 1 and 3).

\section{Availability}

Currently, "NuMex Solano' is being produced, marketed, and sold exclusively by Lockhart Seed Co., Inc., Stockton, Calif. Those individuals interested in acquiring seeds of 'NuMex Solano' should contact Lockhart Seeds. Application for Plant Variety Protection has been filed.

\section{Literature Cited}

Corgan, J.N. 1996a. 'NuMex Crispy' onion. N.M. Agr. Expt.. Sta. Var. Rel. Not.

Corgan, J.N. 1996b. 'NuMex Vado' and 'NuMex Luna' onions. N.M. Agr. Expt. Sta. Var. Rel. Not.

Cramer, C.S. and M.J. Havey. 1999. Morphological, biochemical, and molecular markers of onion. HortScience .

Magruder, R., R.E. Webster, H.A. Jones, T.E. Randall, G.B. Snyder, H.D. Brown, L.R. Hawthorn, and A.L. Wilson. 1941. Descriptions of types of principal American varieties of onions. U.S. Dept. Agr. Misc. Publ. 435. 